\title{
Study on Current Situation and Countermeasures About the Informatization of Internal Audit in Universities
}

\author{
XIA Jing ${ }^{1, a}$, YANG Yin $^{2, b *}$ \\ ${ }^{1}$ Finance Department, Wuhan University of Textile, \\ Wuhan, P.R. China, 430200 \\ ${ }^{2}$ School of Accounting, Wuhan University of Textile, \\ Wuhan, P.R. China, 430200 \\ a e-mail: callidora2015@163.com, be-mail:cs_yangyin@hust.edu.cn \\ *Corresponding author
}

Key words: colleges and universities, internal audit, informatization, construction

\begin{abstract}
As an important part of the internal control, people usually pay more attention to the internal audit in enterprises than that in colleges and universities. Serving as the backbone force in the strategy of rejuvenating the country through science and education, the internal management and control activities of colleges and universities are also very important. This paper mainly discusses problems existing in the internal audit of current colleges and universities and puts forward effective countermeasures.
\end{abstract}

\section{Introduction}

With the development of economy and technology, during the process of management, enterprises attach more and more importance to the information construction. In order to have a share in the fierce competition, they always go faster in employing advanced technology than other subjects in the market. [1] Considering the enterprise finance, as an important part of internal control, the internal audit has already employed the information technology comparatively skillfully which has achieved obvious effects. Colleges and universities cultivate talents whose nature is largely different from that of enterprises. [2] As public institutions, colleges and universities do not have great pressure from the market. However, there are also competitions among colleges and universities including main competition of soft power. That is to say, they compete for the scientific research strength and the quality of students they cultivate. [3] But it has nothing to do with the importance of internal audit in colleges and universities. The internal audit is an important part of university financial management. No matter what department, finance is always the most important part. [4]At present, the informatization has been widely used for financial accounting in colleges and universities, while for inter audit, the employment is not so good. As the backbone force in the strategy of rejuvenating the country through science and education, the information construction of colleges and universities is crucial.

\section{Main content of internal audit in colleges and universities}

Colleges and universities are public institutions which cultivate talents instead of producing profits, while enterprises run business for making money. [5] Therefore, there are some differences of content in the internal audit between colleges and universities and enterprises. The content of internal audit in colleges and universities can be roughly divided into four parts: audit of revenues, audit of expenditure, audit of financial budget and final account and economic responsibility audit. At present, besides fiscal appropriation, the revenue of colleges and universities also includes income of running a school, donation income and income from other sources. If there is only one single channel for the income, the internal audit is comparatively simple. But if there are diversified channels, the internal audit should not only investigate the sources of income but the standards and scopes of investigation to make sure that they are legal and conform to related rules. Besides, they should also audit if the management of the income achieved is rational, if there are corresponding 
bills by rule, if the donation is managed under the name of some special fund and if the fixed sum is for a fixed purpose. They should also consider if there are private coffers in other departments of the school and exercise strict control over the phenomenon of opening several bank accounts. [6] With the expanded enrollment scale, various expenditure of colleges and universities increases. There may be legitimate reasons of course, but factitious and illegal factors may also exist. Rational application and good effect achieved of expenditure will influence the reputation and strength of colleges and universities. Therefore, the audit of expenditure inside colleges and universities is also very important. [7]The expenditure audit should not only care about the procedure but the content of expenditure to see if they are legal and rational. Since our country has certain rules for the scope of expenditure and procedures. Therefore, the procedure of expenditure in colleges and universities should be exercised strictly within the stated range of our country. For the expenditure content, the audit of procurement fund by government and capital construction projects should be attached with great importance because these two kinds of expenditure usually involve lots of money which easily produce corruptions. [8]The financial budget will guide the financial work of colleges and universities in the future. And the financial final cost reflects the financial activities of the previous year. By auditing financial budget and final account, colleges and universities can improve the availability of fund and degree of standardization for the income and expenses. For the economic responsibility audit, it is an effective means of supervision which connects the economic responsibility with relevant principals. But it can only achieve good effects when the relevant principal is on duty.

\section{The current situation of audit informatization in colleges and universities}

In recent years, the education department and colleges and universities pay close attention to the information construction of their internal audit. But the level is lower than state audit and social auditing. This depends on the nature and knowledge of internal auditing staff of colleges and universities. However, colleges and universities have made some progresses in the information construction of internal audit including hardware facility, software facility, the allocation of internal auditing staff and so on. To be specific, for the hardware, almost all the colleges and universities have adopted advanced computers and matched equipment. For the software, many have introduced financial audit software which largely increases the efficiency of inter audit compared with manpower. [9]For the construction of staff, first of all, internal audit staff should be independent of personnel of financial accounting as the internal audit department has gradually become an independent department. Next, the education background and overall quality of internal audit staff employed increase year by year. Though the information construction of internal audit has some basis and has achieved some progresses, there are still many problems.

A. The internal audit staff lacks full understanding.

Though the information construction advocates information technology to increase the efficiency of internal audit, it also requires good specialty literacy of internal audit staff. At present, in the internal audit of colleges and universities, on one hand, some administrative staff is not young with slow knowledge update and low computer ability. They do not have full understanding about internal audit and passion to effectively carry out the information construction of internal audit. On the other hand, some of them misunderstand that informatization of audit is just to have computer hardware, software equipment and other matched equipment.[10] This kind of one-sided understanding makes the informatization of audit become a mere formality.

B. The information communication is at low level.

The informatization of internal audit needs to be set up on the basis of expedite exchange of information. But the audit information of various processes of colleges and universities is discrete. Information collected by staff of different links is not shared but in their respective computers. If they want to use information of other links, they need paper approval from superior class which easily leads to the hysteresis of information transfer and processing.

C. The processing information is also at low level.

The information construction of audit needs modern information technology to process all 
kinds of data. Then people can analyze problems existed in the operation of organization more easily. The informatization liberates some labor force from multifarious information which saves people's much time and energy. But the information construction of internal audit in colleges and universities still rests on the primary stage. Staffs in the internal audit department do not have high computer ability and know little about the powerful information processing function of software.

D. The internal audit department is not independent.

Compared with external audit, the independence of internal audit is weak. If colleges and universities wish that the internal audit practically plays a role of effective supervision and administration in the process of audit, they should pay special attention to the independence of internal audit department. At present, as a branch of finance department in colleges and universities, the internal audit department usually has lower status and weak independence undoubtedly.

\section{Suggestions for boosting the information construction of internal audit in colleges and universities}

A. To improve the status and independence of internal audit

The internal audit is actually a kind of supervision of the operation for the organization. With the gradual expanded scale of colleges and universities, the content to be managed will be more complex. In this situation, more effective internal supervision is needed. However, most colleges and universities just establish a branch in finance department for internal audit. Such internal audit departments exist in name only. They can not function at all. This also reflects that internal colleges and universities have not fully realized the importance of inter audit. To enhance the effect of internal audit, it is a good way to improve its status and independence. For example, if the colleges and universities set up a department which is independent of finance department and under the charge of headmaster, it will supervise better.

B. To increase the level of informatization of internal audit staff

The information construction of internal audit needs talents. Without excellent internal audit staff, even the best hardware can not effectively play the function of supervision. At present, though the quality of internal audit personnel employed by colleges and universities increases gradually, their continue learning is not enough which leads to the hysteresis of knowledge update. To meet the information construction of internal audit, talents are crucial. When colleges and universities set up the independent internal audit department, they should pay more attention to the selection of internal audit staff. Try to choose highly educated young people because such people have ability and energy to acquire new knowledge, and at the same time, they have active thinking during the process of internal control.

\section{Conclusions}

At present, the informatization has been widely used for financial accounting in colleges and universities, while for inter audit, the employment is not so good. As the backbone force in the strategy of rejuvenating the country through science and education, the information construction of colleges and universities is crucial. To solve problems of information communication in the internal audit is to improve the construction of system of information. These mainly are technique problems which can be effectively solved by designing the software. Besides, for the complex information, even aided by the system of information, it also needs lots of manpower for the analysis by synthesis. Therefore, it is necessary to advocate the exchanges and cooperation among internal auditing staff.

\section{References}

[1] Abdulrahman A.M Al-Twaijry,John A Brierley,David R Gwilliam. THE DEVELOPMENT OF INTERNAL AUDIT IN SAUDI ARABIA: AN INSTITUTIONAL THEORY PERSPECTIVE[J]. Critical Perspectives on Accounting. 2003 (5) 
[2] Brown, L. D,A. S. Pinello."To What Extent does the Financial Reporting Process Curb Earnings Surprise Games? ". Journal of Accountancy . 2007

[3] The Institute of Internal Auditors.The Statement of Responsibilities of Internal Auditor. . 1999

4] John Roberts,Robert Scapens.Accounting systems and systems of accountability understanding accounting practices in their organisational contexts. Accounting Organisations and Society . 1985

[5] David Mcnamee,Gorges Selim.Audit Fees:A Meta-analysis of the Effect of Supply and Demand Attributes. Contemporary Accounting Research . 2000

[6] Zilla Sinuany-Stern,Abraham Mehrez,Arieh Barboy.Academic departments efficiency via DEA. Computers and Operations Research . 1994

[7] An Audit of Internal Control over Financial Reporting Performed That Is Integrated with An Audit of Financial Statements. PCAOB.Auditing Standard No.5 . 2007

[8] Brinkman P. T."Factor Affecting Instructional Costs at Major Research Universities". The Journal of Higher Education . 1981

[9] Sarens,G.A Research note on the relationship between the control environment and the size of the internal audit function in Belgiim. . 2007

[10] Pekka Korhonen,Risto Tainio,Jyrki Wallenius. Value efficiency analysis of academic research[J]. European Journal of Operational Research . 2001 (1) 